\title{
The Role of Training, Democratization, and Self-Actualization in Addressing Employee Burnout
}

\author{
Randa El Bedawy ${ }^{1}$, Omar Ramzy ${ }^{2}$, Aya Maher $^{3}$, Omar H. Eldahan ${ }^{2}$ \\ ${ }^{1}$ Misr International University, Egypt \\ ${ }^{2}$ Heliopolis University for Sustainable Development, Egypt \\ ${ }^{3}$ German University in Cairo, Egypt \\ Correspondence: Randa El Bedawy, Faculty of Business Administration and International Trade, Misr \\ International University, Egypt.
}

Received: June 8, 2017

doi:10.5539/ibr.v10n8pxx

\author{
Accepted: June 28, $2017 \quad$ Online Published: July 11, 2017 \\ URL: https://doi.org/10.5539/ibr.v10n8p93
}

\begin{abstract}
The objective of this study is to investigate in depth the factors that can reduce the effect of employee burnout in Egypt. From the literature review, the variables of perception of employee development programs (IV1), time spent on employee development programs (IV2), self-actualization (IV3), and workplace democratization (IV4) were identified. To study these variables on employee burnout, SEKEM, a company in Egypt known for its innovative application of human development initiatives, was selected as a case study from Egypt. A single cross-sectional analysis of the employees of the company was used and data was collected with a questionnaire using a 7-level scale.The results were then analyzed with a principal component analysis, Cronbach's alpha, and Spearman's rank correlation. The results confirmed the validity and inter-reliability of the model as well as showed the significant negative relationship between both IV1 \& IV3 and between employee burnout. IV2 and IV4 were not found to be significantly related to employee burnout.The significance of the research is that few studies in Egypt are made on the issue of employee burnout, and the study of SEKEM provides a rare insight into the application of such concepts.
\end{abstract}

Keywords: employee burnout, workplace democratization, self-actualization, employee development, human energy, human resource management

\section{Introduction}

Employee energy is recognized as an important factor for the successful performance of any organization. Over the last 20 years, it has been noticed that there has been a dramatic increase in public and business interest in building sustainable organizations that have the capacity to endure and be productive over time. Thus, within the workplace context, human energy is a "fuel" that helps organizations run successfully. However, demands very often exceed their capacity, resulting in lower productivity in a phenomenon known as employee burnout. Despite the proliferation of the signs of burnout in organizations throughout the world, it is still not addressed sufficiently - especially in developing countries such as Egypt.

Human energy is one resource that helps people regulate their behaviors and emotions to meet performance expectations. Most of the employees report feeling overworked, and pressured, to the point of anxiety, and depression. Actually, the problem is also getting worse due to the severe competition and rapid market changes. According to Spreitzer \& Grant (2011), "Like a battery, human energy can be depleted over time if not regularly recharged". Accordingly, the depletion of human energy is actually a type of energy crisis that must be avoided.

The objective of this study is to investigate in depth the factors that can reduce the effect of employee burnout at workplace in Egypt.The variables of perception of employee development programs, time spent on employee development programs, self-actualization, and workplace democratization were examined. To study these variables on employee burnout, SEKEM, a company in Egypt known for its innovative application of human development initiatives, was selected as a case study from Egypt.

\section{Literature Review}

Work Energy and Employee Burnout are aspects that have been studied extensively in the literature. In this 
section, the different definitions, concepts, and understandings of these phenomena are reviewed with the purpose of developing a theoretical framework to better explaining the relationship between these concepts as well as the tools for addressing the resulting of employee burnout problems.

\subsection{Defining Energy at Work}

Energy can refer simply to the essence that allows us to perform physical, mental or emotional tasks (Schiuma et al., 2011). When we can work hardly and still with a smile, then we are usually motivated and a main factor in our success is our energy. Energy at work is not just our physical or mental power to work but actually it is much more an indefinable characteristic that can be considered in turn a base to reach and maintain a competitive edge (Schiuma, Mason, \& Kennerley, 2011). The origin of "energy" is the Greek words 'energeia /energos' meaning "activity, operation, active, working". In turn, the success of any organization depends on its ability to maintain energetic employees (Taylor, Schwandt, \& Casey, 2011).

According to Quinn, Spreitzer, \& Lam (2012), energy is "the capacity to do work". However, some motivation scholars define energy as a type of resource that people can invest along (Quinn et al., 2012). Energy can be both a short-term and a long-term process. Long-term draining effects can result in a burnout which is perceived as deviations from persons' basic energy level (Schippers \& Hogenes, 2011).

Taylor et al. (2011) defines human energy at work as 'the force or power of human movement, action, change, or being". Then, human energy can be seen as the source or origin of human work. Thus, human energy is a required "fuel" to run organizations successfully. Yet, it is a limited resource that can be replenished as it can be depleted over time due to work demands (Fritz, 2011). Accordingly, employees need to find ways to replenish their energy on a regular basis as well as to lower levels of fatigue at the end of the weekend (Fritz, 2011). In this regard, human energy is a fundamental component of work motivation and in turn to maintain successful organizations.

\subsection{Energy Management}

According to Spreitzer \& Grant (2011), there are four levels for energy management that can be presented as a pyramid where physical energy can form the base for mental energy which can form the base for emotional energy, which in turn is the base for spiritual energy.There is actually an interconnection between motivation and energy as motivation needs energy to be realized (Schiuma et al., 2011). Energetic and motivated employees are crucial for any organization's success as they are generally more productive and creative (Schippers \& Hogenes, 2011).

\subsection{The Employee Burnout Phenomena: Job Burnout and Job Stress}

Employees nowadays are working harder, longer hours and are experiencing higher levels of stress. Thus, it is not surprising that employees in contemporary organizations are beginning to run out of energy or, in other words, experience burnout. Burnout is an extreme form of stress representing emotional exhaustion, depersonalization of others, and lack of felt accomplishment in working with others (Jawahar, 2012). Stress becomes a common feature of the modern workplace and has been identified as one of the major factors associated with job dissatisfaction and job burnout.

Several studies have confirmed a negative relationship between job satisfaction and employee burnout (Maher \& El-Bedawy, 2014; Steffens, Haslam, Kerschreiter, Schuh, \& Van Dick, 2014; Wang, Zheng, Hu, \& Zheng, 2014). Job satisfaction reflects the degree to which a person's needs, or expectations are met at work and represents the degree of satisfaction with one's work, co-workers, supervisors, promotional opportunities, pay scale, and organizational setup. Both satisfaction and dissatisfaction represent a relationship between what one wants from a job and what one perceives to be getting from the job (Wang et al., 2014). If they feel that the organization is unable to meet their expectations, employees feel less satisfied and accordingly are more inclined to leave the organization (Kar \& Suar, 2014). Job burnout has been then a serious problem along various workforces in modern societies (Chen, Wu, \& Wei, 2012).

Complexity of a job such as task difficulty, confusion, or rapid decision making can lead to occupational stress (Kar \& Suar, 2014). Developmental tasks put employees into risks and uncertainties, which will increase their feelings of frustration, anxiety or fear about performance failure (Dong, Seo, \& Bartol, 2014). Stressful feelings are subjective and certain events can produce complex emotional states, such as a mixture of anger and worry (Mortillaro \& Scherer, 2014). That's why companies should reduce stress for their employees. One option is to organize training sessions that actively address emotional competence and stress management (Mortillaro \& Scherer, 2014).

Job stress can be defined as the harmful physical or emotional responses that occur when the requirements of the 
job do not match the employees' capabilities, resources, or needs. Job stress occurs as well when the source of stress exceeds the individual's capacity to resist. Accordingly, job stress can predict numerous negative outcomes such as job dissatisfaction and job burnout (Wang et al., 2014). Prolonged exposure to stress can lead to burnout which is a state of physical and mental exhaustion that happens when employees are subjected to prolonged periods of stress within their work environment.

Burnout reflects emotional exhaustion, depersonalization, and personal non accomplishment. Employees' stress and burnout are generally recognized to have a negative effect on both employee health and organizational performance (Hollet-Haudebert, Mulki, \& Fournier, 2011; Kar \& Suar, 2014). Burnout has reached a critical stage among today's workforce because of workplace demands such as role conflict, role ambiguity, work load, work-home conflict, shift work attitudes, job complexity, physical environment, and organizational politics, all of which are positively associated with emotional exhaustion (Kar \& Suar, 2014).

Furthermore, according to (Wang et al., 2014), job burnout is a multidimensional concept and reflects three components. First is the emotional exhaustion which is the feeling of being emotionally overextended and exhausted by one's work. Second is depersonalization which is the unfeeling and impersonal response toward recipients of one's service, care, treatment, or instruction. Third is personal accomplishment which is the feeling of competence and successful achievement in one's work with people (Wang et al., 2014). Burnout has been defined as a long-term consequence of aversive working conditions, characterized by the simultaneous experience of the symptoms of exhaustion and disengagement from one's job.

Disengagement refers to distancing oneself from one's work object, work content, and work in general (Demerouti, Bakker, \& Leiter, 2014; Russell, Cole, \& Jones, 2014). Burnout can lead to diminished job performance because of two reasons. First, job stressors or demands reduce individuals' capacity to exert control over their work environment, which in turn adversely affects their ability to function effectively. The second reason is because of fatigue that represents the intolerance of any effort. According to Chen et al. (2012), job burnout comprises three sets of factors: organizational characteristics such as systems or resources, work characteristics such as job type, or workload, and individual characteristics such as demographic, or personality. Accordingly, job burnout can have three subcomponents: work weakness-caused burnout, organizational weakness-caused burnout, and individual characteristic-caused.

The phenomenon of burnout can also be reflected by frustration, disappointment, emotional breakdown and it plays a role on the employees' turnover in the organization's life cycle (Yüksel, 2014). Fatigue reflects the inability and also the unwillingness to expend effort, reflecting both exhaustion as well as disengagement. Accordingly, burned-out workers are unable and unwilling to expend effort as burnout is characterized by emotional exhaustion (Demerouti et al., 2014; Verma \& Verm, 2012). Burnout is a significant concern to organizations because of its costs in terms of lower job performance, higher turnover, lower organizational commitment, higher health care costs, and reductions in creativity and innovation. Job-provided de velopment opportunities were significantly related to satisfaction with growth opportunities, which, in turn, was related to the citizenship behaviors.

From an employee's perspective, it is crucial to continuously update one's skill set to avoid a layoff and also to be confident of finding a suitable job in the event of a layoff. However, from an employer's standpoint, providing challenging jobs and affording employee development opportunities is critical to maintaining a motivated workforce (Dong et al., 2014; Jawahar, 2012). Research has suggested that high-commitment human resource practices as employee development affect organizational outcomes by influencing employee behaviors and attitudes. Investment in employee development represents a high-commitment strategy that affects employee commitment and motivation, and offers the organization a competitive advantage (Dong et al., 2014; Jawahar, 2012).

\subsubsection{Strategies Employees Use at Work to Increase their Energy}

There are various 'Physical, Relational, Mental or Spiritual' strategies that can be enriching human energy at work such as taking a break to fulfill basic physiological needs, or interacting with people in a positive manner or making plans for the future or perceiving the meaning of one's work (Fritz, 2011). To manage human energy at work, Schippers \& Hogenes (2011) pointed out as well main practices such as planning for long-term goals, adding to physical fitness.

\subsubsection{Individual Strategies Related to Vitality and Fatigue at Work}

The energy management strategies found to be most positively related to setting a new goal, learning something new or focusing on what can give joy at work (Fritz, Lam, \& Spreitzer, 2011). When people are learning, they 
become open to new things rather than being resistant to change, which further increases vitality. In terms of relationships at work, recent research suggests that positive relationships at work are energizing, both physically and emotionally (Dutton \& Heaphy, 2003). Moreover, it was found that individuals who were able to energize others reflected themselves as input for higher level of job performance (Fritz et al., 2011).

\subsubsection{Employee Engagement through Training and Development}

Strategic human resource management emphasizes the importance of investing in human resources to create and sustain the organizations' competitive advantage (Jawahar, 2012). Many researchers confirmed that employees who are engaged, are also more productive, whereas employees lacking energy show deteriorating performance (Demerouti et al., 2014; Stankiewicz, Bortnowska, \& Lychmus, 2014). Employee engagement refers to the extent to which employees are motivated to contribute to organizational success and intend to remain with their organizations (Wiley, 2014).

Given the importance of continuous human resources development, employees usually expect from their organizations to provide them with development opportunities as they perceive it as important aspects of the psychological contract. Effective utilization of employees' energy and retaining them is one of the biggest challenges that face the organizations. Employee engagement can affect employees' contribution for organizational success. Accordingly, employee engagement is an emerging concept that addresses various challenges that organizations are facing nowadays such as profitability, customer satisfaction, and business productivity (Bhuvanaiah \& Raya, 2014). Human resource management has a positive impact on the company's competitive advantages, as innovation, and adaptability come basically from human resources. Accordingly, employees are required to continuously learn new knowledge and skills for better performance. Human resources development practitioners play significant roles through training and organizational development efforts (Cosby, 2014).

Training and de velopment can play a crucial role in increasing necessary competence and motivating employees. In addition, training and development practices can promote entrepreneurial behavior and encourage high employee participation. Human resources development is a process of developing human expertise through organization development and personnel training for the purpose of improving organization's performance (Russ-Eft, 2014). Training refers to activities that provide employees with required skills to perform better in their current jobs based on an assessment of employees' strengths and weaknesses. According to Suttapong, Srimai, \& Pitchayadol (2014), training can generally improve employees' technical skills and interpersonal skills, as well as can upgrade employees' performance, adding to prepare employees for future job assignments.

Training can then make a positive contribution to the overall effectiveness of the organization through empowering employees. Training also provides employees cross functional perspectives and a support for cooperative behaviors. All in all, training can develop a productive human resources which is required for any organization's success (Suttapong et al., 2014). The work plays a very critical role of any individuals' life through meeting the psychological and social needs (Yüksel, 2014). The current unpredictable environment creates a threat of losing one's job. Therefore, satisfaction with growth opportunities can provide assurance that in case of a job loss, the employee has the necessary skills and competencies to find suitable employment. Accordingly, employees who are satisfied with growth opportunities, have usually lower levels of emotional exhaustion and higher levels of personal accomplishment (Jawahar, 2012).

Investing in human resources through training and de velopment activities enhance positive work behaviors that are necessary to maintain a competitive advantage. Actually, satisfied and motivated employees engage in citizenship behaviors which can as well support organizational effectiveness (Jawahar, 2012). Developmental activities provide better opportunities to perform new tasks that employees will find interesting, as they are then more likely to experience positive feelings such as enthusiasm and enjoyment. By developing employees' competences, organizations can enhance their stock of human capital to reduce the costs of recruiting and selecting external new hires to fill managerial positions (Dong et al., 2014).

$\mathbf{H}_{1}$ : Positive perception of employee development programmes is negatively correlated with employee burnout.

$\mathbf{H}_{2}$ : Time spent on employee development programmes is negatively correlated with employee burnout.

\subsection{Employee Engagement through Workplace Democratization}

The concept of workplace democracy is a term that emerged with the labor union movements to support the rights of labors in the absence of labor freedom of expression in UK and US. According to Harrison \& Freeman (2004), workplace democracy can be described as any action or a change in the organizational structure or the internal process of the organization that allows workers to influence the decisions of their organizations. Despite 
the fact that there are many definitions for workplace democracy, there are common concepts and themes for it in almost all studies. The common definitions for workplace democracy imply the necessity for labor freedom and rights in the presence of equality, collective decision-making, and participation.

The terms used by scholars for workplace democracy include industrial democracy, organizational democracy, participatory democracy, worker participation, workers' control, etc... (Collom, 2001). Due to the need of a more unified definition, work place democracy was defined by Harrison \& Freeman (2004) as "any action, structure, or process that increases the power of large group of people to influence their organization's decisions and activities can be considered a move toward [workplace] democracy".

The growing role of human resource management instead of the traditional personnel, with the rise of global competition, had placed much emphasis on employees' rights and well-being. Most studies came up with the general core requirements for workplace democracy in organizations which can be summarized in fulfilling the following (Luhman, 2006; Markowitz, 1996):

- Open communication internally and externally.

- Open governance and decentralization of power, decisions and responsibility to lower level employees.

- Freedom given to labor to express themselves and be given discretion to choose.

- The right for labor to have meaningful work.

- No discrimination for gender or ethnicity.

- Less supervision or narrow span of control with some authority and responsibility given to labor.

- More worker control over the functions that impact them.

- Availability of trust and rapport between top management and workers with less fear to question control or some issues related to them.

- Smooth flow of information inside the organization.

- The freedom of expression given to workers to disc uss job design, work requirements and quality.

- Team based organization structure or flattened with non-hierarchical controls.

However, workplace democratization is not simply about the rights provided to employees, as "workplace democracy is not possible without meaningful work" (Mason, 1982). As such, workplace democracy is not only a method for enhancing workers' rights, but its purpose and implementation are directly related to the well-being of the institution itself. In fact, it has been found that the implementation of workplace democracy will affect organizations positively. These impacts, according to (Grady, 1990; Harrison \& Freeman, 2004; Holtzhausen, 2002; Luhman, 2006), can be summarized in the following points:

- Work place democracy allows individuals to have control over their work.

- The representation of women and unrepresented groups in the organization is enhanced when democracy exists in the workplace.

- Work place democracy enhances employees' quality of work life which helps with their knowledge and competency.

- The participation involved in the workplace democracy helps build employees' commitment, responsibility and employees' citizenship.

$\mathbf{H}_{3}$ : Workplace democratization is negatively correlated with employee burnout.

\subsection{Self-Actualization in the Workplace}

The concept of self-actualization is quite old to psychologists and has been described as the realization of one's potential and self which is the key component of one's success (Ozsoy, 2010). 'Self-actualization' has been attributed to people who are capable of realizing their own potential; they have a balanced view of themselves, are self-confident, and have self-esteem. Self-actualized people use their strength in reaching their goals (Goldstein, 1939; Maslow, 1943). Psychologists believe that individuals who are self-actualized are usually satisfied with their life. According to William James, the self consists of three components which are the 'material or bodily' component of the self that includes anything the person possess, the 'social' component of the self that implies the social roles within the social environment, and the 'spiritual' component of the self that comprises our feelings and thoughts about ourselves (James, 1890).

Maslow's Hierarchy of needs categorized 'self-actualization' on top of the pyramid or the attainment of 
individuals basic needs of physiological, safety/security, love/belongingness, and self-esteem (Maslow, 1943). Self-actualization can be achieved when a person explores his talents and capabilities and acts on them. Many scholars discussed the concept of self-actualization with its relation to one's talents and creativity or using one's talents and potential to be capable and in control of becoming what you want to be. As such, creativity and self-actualization were found to be strongly related. Furthermore, Maslow emphasized self-actualization as the tendency of a person to be self-fulfilled from doing what he can do more and more. Self-actualization leads a person to accept him/herself, feel in control of one's life, grow forward and be emotionally stable. The deeper the person realizes and explores himself, the closer he reaches self-actualization (Maslow, 1987).

In this context of self-actualization, it is important to note that these concepts can be heavily reinforced by the workplace itself. If an organization emphasizes and promotes employee engagement in creative and social endeavors, then such an organization is playing its part in promoting the self-actualization of its employees. As such, an organization that has its ideals, goals, and purposes, closely related to that of its employees and surrounding community, is an organization that attempts to fulfill its employees' purpose, a level higher than by more material and financial rewards, and can motivate its employees beyond what these material rewards.

$\mathbf{H}_{\mathbf{4}}$ : Self-actualization at the workplace is negatively correlated with employee burnout.

\subsection{Case Study: SEKEM}

SEKEM is a unique company in Egypt and makes it singularly interesting and important to study and analyze. Its success further makes it important to research for other companies to attempt, to emulate and to apply its concepts. The philosophy of the organization is grounded in its name, for SEKEM as is a "hieroglyphic word which means vitality" (Ramzy \& Wahieb, 2012). As SEKEM's overarching vision is one grounded in the concept of Sustainable Development (SD) (Khalil, Ramzy, \& Mostafa, 2013).

SEKEM has always placed great importance in the concept of SD, and has infused its concepts into all of its operations, which includes its employees. In terms of SEKEM's human resources, SEKEM follows the concept of human development through a variety of programs relating to weekly forums, discussions with the CEO and chairman of the board, activities in the various arts, eurhythmy sessions, guest lectures and visits from experts in SD from around the world, and a host of other activities. This is in addition to how it includes its employees in the decision making process, its commitment to women and minorities, and its overall commitment to a higher goal.

For these reasons, SEKEM is uniquely situated to measure all of the factors and variables previously mentioned. In Egypt, companies that engage in such activities are a rarity and the availability of this organization for study allows for a look into a highly successful organization which may provide insights into how these variables impact employee burnout, and from these results come up with recommendations for other organizations around Egypt to apply.

\section{Conceptual Framework}

The review of literature shows the different factors that affect human energy and burnout which can be manifested in the conceptual framework in Figure 1. From the established hypotheses gleaned from the literature review. 


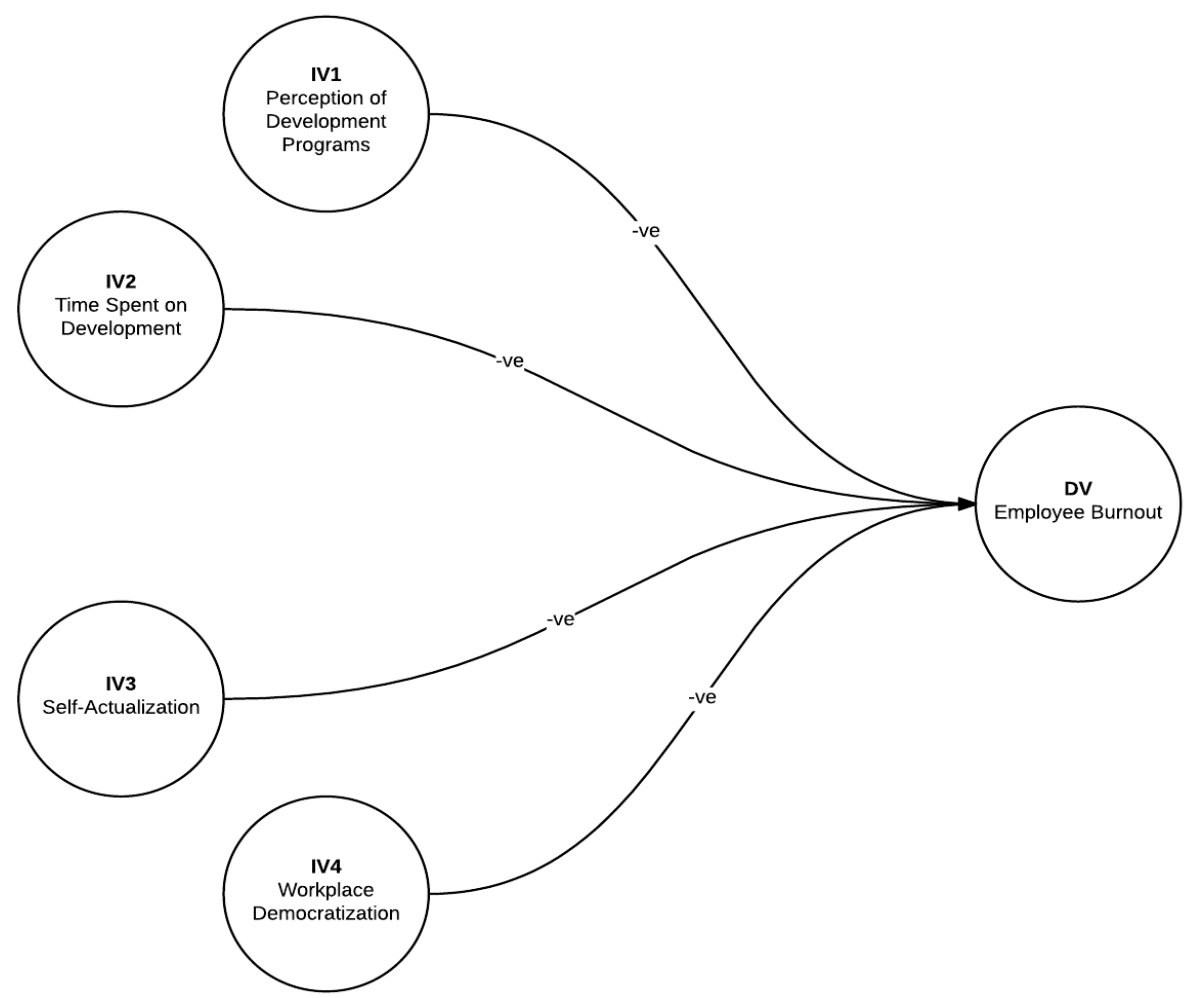

Figure 1. Conceptual Framework of Factors impacting Employee Burnout

\section{Methodology}

The purpose of this study is to obtain a greater understanding of the different factors that can impact (or reduce) the drainage of human energy and employee burnout. For this study, an Egyptian company which has pioneered the use of various techniques for employee engagement and development was selected. The company chosen was SEKEM which is the parent company of various initiatives in Egypt related to sustainable development. As an extension of this concept, human development has always been at the forefront of its endeavors and it strives to engage all of its employees in various activities and programs for the entire duration of their employment.This institution is taken as a case study in terms of what can be achieved through the use and implementation of various developmental activities in addressing the aforementioned issues.

As such, the researchers conducted a single cross-sectional analysis of the employees of SEKEM as well as its affiliates including its NGO, SEKEM Development Foundation, and Heliopolis University for Sustainable Development.The study uses a descriptive, conclusive research design through a quantitative analysis of a questionnaire distributed to the various employees of the companies. The questionnaire was de veloped in English on a 7-level scale. However, since the company is based in Egypt, the help of a local expert was used for translating the questionnaire into Arabic. The data was then gathered an analyzed using SPSS and R the statistical package (R Core Team, 2014).

The data was collected through the distribution of the questionnaire throughout SEKEM. This was accomplished by giving the questionnaires to the HR department at SEKEM Holding which then randomly selected departments to distribute the questionnaire to. The HR department then collected the completed questionnaires and brought them back to the authors for analysis. For Heliopolis University staff, however, an email was sent to all staff in the university as a self-administered online questionnaire.

\section{Anal ysis}

The data collection resulted in a total of 68 valid responses $(n=68)$ out 300 questionnaires sent with a response rate of $22.67 \%$. While this number is somewhat small for a study on these matters, it is important to note that the data is gathered from only one institution and reflects the willingness of participants within the organization to respond to questionnaires as well as the accessibility of the employees. It is considered that this number of respondents is sufficient to get an accurate view into the inner workings of SEKEM and extrapolate the necessary inferences.

An exploratory factor analysis was used in to measure the validity of individual constructs (Mourad, Ennew, \& 
Kortam, 2011). As such a principle component analysis was used with a direct oblimin rotation. The direct oblimin was selected due to the hypothesized correlations between the components.

Furthermore, a KMO and Bartlett's test was used to measure the significance and validity of the entire model as seen in Table 1. From this test, a high degree of consistency was found between the different variables and components in tandem with the questions' and variables' original design.

Table 1. KMO, Bartlett's Test, and Variance Explained by PCA

\begin{tabular}{ccc}
\hline \multicolumn{1}{c}{ Test } & Value \\
\hline KMO measure of sampling adequacy & .786 \\
\hline Total Variance Explained & & $71.52 \%$ \\
(5 Factors) & Approx. Chi-Squ & 877.297 \\
\hline \multirow{2}{*}{ Bartlett's test of sphe ricity } & df & 210 \\
& Significance & .000 \\
\hline
\end{tabular}

In Table 1, it can be seen that the KMO test is more than adequate with a value greater than $0.5(0.786)$ and Bartlett's test of sphericity is found to be significant $(\mathrm{P}<0.01)$. These values provide confidence that the questions were successfully loaded into 5 factors in total which explain $71.52 \%$ of the total variance of the model.This is considered an acceptable amount, and as such a component matrix and pattern matrix were conducted.

A component matrix was then established with absolute values less than 0.3 being suppressed in order to view the relationships between the varying questions. The results are as follows in Table 2.This was followed by a pattern matrix, shown in Table 3, sorted by highest to smallest value in the individual components. Values less than 0.30 were suppressed and values of questions in components other than intended were removed.The resulting values confirm to a high degree the validity of the model.In addendum, a Cronbach's Alpha was used to measure for inter-reliability of the model with all variables resulting of an alpha representing strong reliability with $\alpha>0.7$ (Tavakol\&Dennick, 2011).

Table 2. Principle Component Analysis - Component Matrix (Values < 0.30 suppressed)

\begin{tabular}{|c|c|c|c|c|c|}
\hline \multirow{2}{*}{ Question } & \multicolumn{5}{|c|}{ Component } \\
\hline & 1 & 2 & 3 & 4 & 5 \\
\hline IV3.2: I am proud to tell others that I am part of this organization. & .783 & & & & \\
\hline $\begin{array}{l}\text { IV1.4: I feel that the development programs that I engage in have a } \\
\text { positive effect on my life }\end{array}$ & .766 & & & & \\
\hline IV3.1: I find that my values and organization's values are very similar. & .763 & & & & \\
\hline $\begin{array}{l}\text { IV3.7: Working in my organization makes me feel special compared to } \\
\text { employees of other companies }\end{array}$ & .760 & & & & \\
\hline $\begin{array}{l}\text { IV1.1: I feel that the development programs offered by my work are } \\
\text { useful }\end{array}$ & .736 & & & & -.351 \\
\hline IV1.2: I enjoy engaging in the activities offered in my workplace & .720 & & & & -.313 \\
\hline IV3.6: My work helps me pay my dues to society and the world & .688 & -.441 & & & \\
\hline $\begin{array}{l}\text { IV 1.3: After participating in a development program, I feel more } \\
\text { relaxed }\end{array}$ & .686 & & & & -.353 \\
\hline $\begin{array}{l}\text { IV3.3: I find that in my work, I do what is most important to me in my } \\
\text { life and strive towards achieving those things. }\end{array}$ & .655 & -.559 & & & \\
\hline IV3.5: I feel a high sense of achievement from my work & .621 & -.444 & & & \\
\hline IV3.4: I feel that, through my work, I contribute to my community & .597 & -.566 & & & \\
\hline IV4.3: I feel like my opinion is valued by management & .551 & .463 & & -.395 & \\
\hline DV1.1: I feel very tired while doing my job & -.537 & .494 & & & \\
\hline $\begin{array}{l}\text { IV4.2: Management usually asks for feedback and opinions from } \\
\text { employees before making a decision }\end{array}$ & .491 & .643 & & & \\
\hline $\begin{array}{l}\text { IV2.2: How many hours per week does your employer provide personal } \\
\text { or professional development? [Hours/Week] }\end{array}$ & & .555 & & .520 & .355 \\
\hline DV1.3: Lately, I am always feeling exhausted & & & .712 & .332 & -.354 \\
\hline $\begin{array}{l}\text { DV1.4: Lately, it has been difficult for me to get out of bed to go to } \\
\text { work }\end{array}$ & -.403 & & .621 & & \\
\hline DV1.2: I find it hard to focus on my work & -.335 & & .571 & .337 & \\
\hline $\begin{array}{l}\text { IV4.4: I find that employees of my organization help shape the vision } \\
\text { and long term plan of the company }\end{array}$ & .357 & .392 & .393 & -.322 & \\
\hline IV4.1: I am usually included in the decision making process & .498 & & & -.512 & \\
\hline $\begin{array}{l}\text { IV2.1: How many hours per week do you engage in these programs? } \\
\text { [Hours/Week] }\end{array}$ & & .428 & & .379 & .600 \\
\hline
\end{tabular}


Table 3. Cronbach's Alpha \& Principle Component Analysis - Pattern Matrix Rotated by Direct Oblimin with Kaiser Normalization (Values $<0.30$ suppressed)

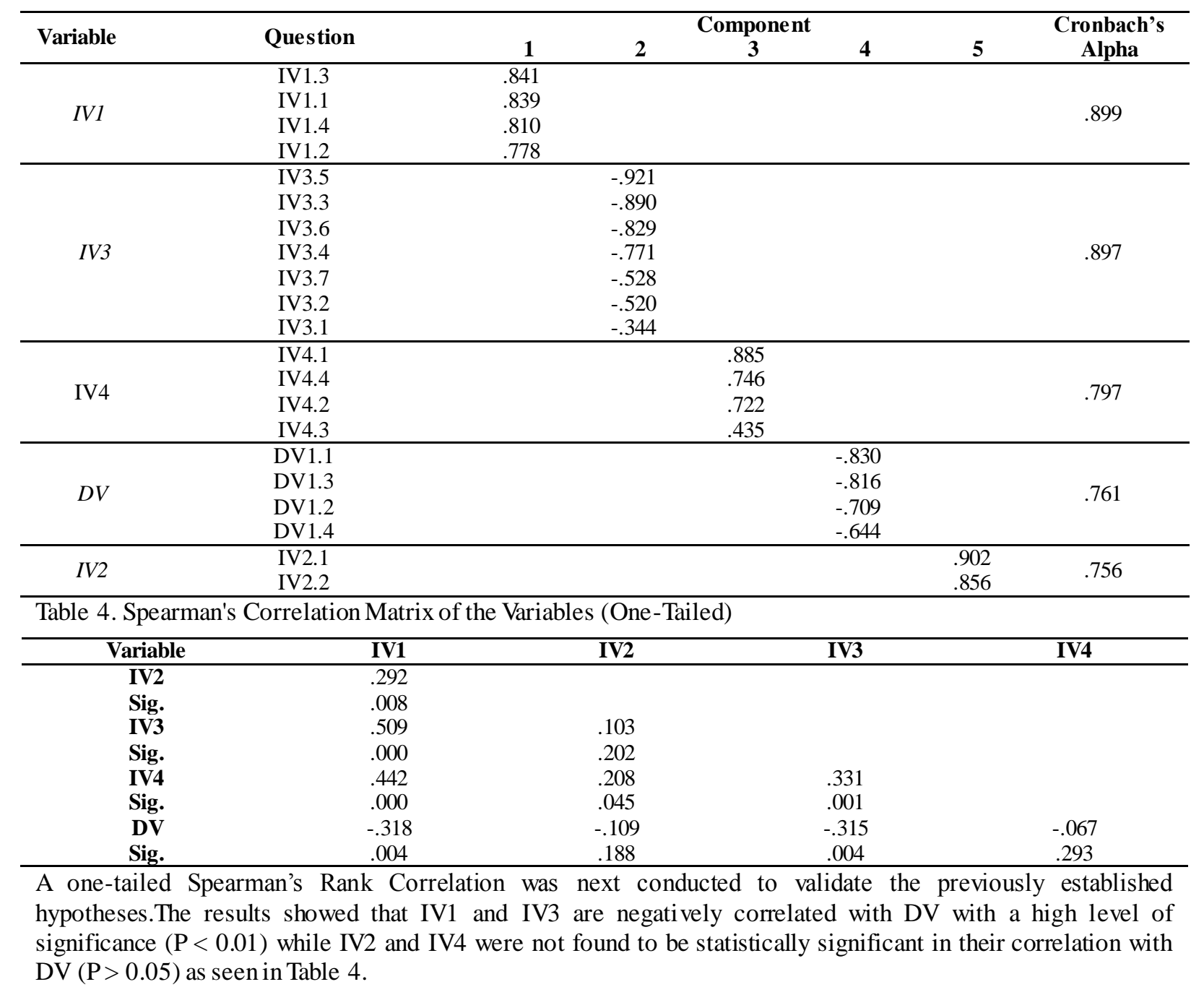

\section{Discussion}

The results of the analysis hypothesis testing bring about some important realizations; that the time and quantity of training and de velopment programs alone cannot make up for a lack of employee engagement, that the impact of workplace democratization and its benefits are far more complex and multi-faceted to merely explain the single dimension of employee burnout. However, it is the significance of the impact of the perception of developmental programs which are truly of note.

By definition the developmental programs, and in particular the practical and engaging types, should be positively perceived by the employees performing them, as lacking a positive perception or association severely limits the effectiveness of such initiatives.Thus, these programs must be designed to be perceived as formal exercises for the purposes of relaxation, empowerment, inspiration, and even entertainment during regular working hours. Referring to SEKEM case, most of such programs that employees engage with, are participatory programs that blend spiritual thoughts with cognitive or philosophical dimension. This blending exercise is very much welcomed by many employees as they are able to express their very deep insights without any abiding rules or restrictions.

This sentiment, however, is not shared by all employees, thus resulting in the discrepancies in the results of statistical analysis between the perception and the time spent on the developmental programs. It is interesting to note here, that perhaps comes in one of the most significant roles workplace democratization can play in such programs. A discussion with the HR department revealed that while many employees experienced a higher level of democratization, employees felt that they had no say in determining the actual developmental activities offered and conducted by the institution. It is here, perhaps, that we find why the democratization process did not 
reveal, nor could it predict, a lower level of burnout.

It is here, also, that institutions may fall into a dangerous caveat. As it is not important for employees to spend more time in developmental programs so as to reduce their burnout effect, a different phenomenon may emerge. Considering that the employees may not be interested, invested, or even willing to participate in (what may be mandatory) developmental programs, the opposite of the intended effect may occur. It is possible that the long time spent on developmental activities could increase the burnout effect if said employee was under work pressure and thus perceiving the developmental activities as another workload or as an irrelevant misplaced activity on top of one's regular list of responsibilities.

On further scrutiny of the lack of impact of workplace democratization on burnout, some possible explanations emerge. In particular, the aspect of company ownership or increased shared responsibility of the well-being of the organization may play a role in increasing the burnout and stress levels of employees.With employees sharing in the successes and failure of an institution, it is expected they would also share in shouldering responsibility. Democratization can still be used as a tool for reducing stress and burnout, but such possibilities are beyond the scope of this study.

As the self-actualization variable was considered to be statistically significant, it is then easy to say that self-actualization is an essential aspect of increasing employee satisfaction; howe ver, the way to achieve such a sense is lost on most. In the case of a concept defined only in the most personal terms to the one experiencing it, it would be impertinent to assume that one can provide the path to such a sense of self and empowerment.The most that can be done, however, would be to discuss the path that SEKEM has used in an attempt to understand how to bring about such a sense to employees across Egypt, and perhaps the world. According to a manager at SEKEM when shown the results of the analysis, it was stated that:

"In SEKEM, self-actualization is realized when people's ideas and thoughts are appreciated and discussed. Most of SEKEM's developmental activities depend on introspection sessions that link people's minds together. It is the snowballing effect that is thus very much motivating for all participants as their ideas are fine-tuned and agreed upon. For this standpoint, there is a logical, direct connection between self-actualization and reducing the burnout effect."

\section{Limitations}

The most significant limitation of the study comes from the ability to generalize. While attempts were made to randomize the respondents as much as possible, the results came from only a single organization and with a relatively small sample size. Further limitations are found in the nature of the organization selected.While SEKEM was selected due to its commitment to employee and human development, the number of companies in Egypt that can be considered comparable to SEKEM are few to none. As such, SEKEM's adherence and application of sustainable development principles makes it difficult to ascertain if the results from its employees can truly be applied elsewhere in Egypt.

\section{Future Research}

The implications for future research are clear; increased empirical review of the factors impacting burnout. As this study was somewhat limited in scale, future research widening the scope of the study and going to various companies and increasing the sample size are required. Moreover, further research could be conducted into the relationship between the developmental programs instituted by an organization and the level of sense of self-actualization of employees as well as their sense of democratization. This could prove to be valuable in terms of understanding how to guide employees in reaching a higher sense of self and thus achieve higher job satisfaction, lower burnout, and reduce stress. Furthermore, studies examining the impact of workplace democratization in Egypt are needed moving ahead, especially since Egypt is (hopefully) entering a new era of freedom and democracy. Such concepts trickling down from the political level to the micro level on an organization scale should be studied extensively to help understand (as well as shape) the future of Egyptian business.

\section{Conclusion and Recommendations}

It is increasingly apparent that organizations across the world hold the tools and ability to re duce employee burnout and thusly improve their own productivity. By implementing training and development programs, not only can an organization improve its employee's abilities, capacities, and competencies, but the threat of losing a significant portion of the employees' productive power can be significantly reduced.

On the issue of providing employees a sense of self-actualization, this aspect may be more difficult for organizations to emulate; especially in the context of what may be considered more mundane activities. However, 
this aspect does not have to be demonstrated within the confines of the actual work done.Through encouraging employees to engage in activities that would benefit the surrounding, the society and community, while fostering a sense of community, and even through developing the employees' knowledge, skills, and abilities, can all help in allowing employees to become more self-actualized and thus reduce the impact of employee burnout.

It is thus recommended that companies begin to explore the possibility of applying non-traditional training and development programs for its employees for both human de velopment reasons as well as for the sake of fostering a higher sense of self.These programs can take influence from institutions like SEKEM in terms of the various activities that may encourage such positive energy; howe ver the aspect of copying directly must be avoided.To each unique corporate culture goes its own development program which can bring about positive employee growth and empowerment. And it is through these programs that employees will begin to feel the sense of self as well as a sense of community and loyalty to the organization, thus increasing output as well as benefits to the surrounding society.

On another note, it would be dangerous to consider the lack of correlation of workplace democratization and employee burnout as a reason to limit a democratization process; the benefits of workplace democratization are well studied and shown in the literature. While democratization may not be directly related to reducing burnout, the increase in job satisfaction and gaining more insights from employees in the decision making process is more than sufficient to justify such an action. This is all also considering that the results of this study's analysis remain even under increased empirical scrutiny.

Another key takeaway of this study is in the discrepancy between the perception of the development activities and the actual time spent on them.This section clearly demonstrates that no matter the time spent on the developmental activities, it will not have an impact unless the employee is actually invested in the programs provided. As such, with this takeaway it is important to have a constant stream of employee feedback with any developmental programs conducted by the organization; as it is the acceptance of the programs which will eventually bring results and reduce employee burnout.

Realizing the human element in the organization, as a key factor for its success, is the first step in realizing the organization's full potential. By recognizing the factors reducing the value of one's human resources and by understanding the 'human' aspect of human resources, it is critical for utilizing and leveraging untapped productivity. Through this understanding, the beginning of a 'sustainable enterprise' can start to emerge.

\section{References}

Bhuvanaiah, T., \& Raya, R. P. (2014). Employee Engagement: Key to Organizational Success. SCMS Journal of Indian Management, 11(4), 61-71.

Chen, H., Wu, P., \& Wei, W. (2012). New Perspective on Job Burnout: Exploring the Root Cause Beyond General Antecedents Analysis. Psychological Reports, 110(3), 801-819. https://doi.org/10.2466/01.09.13.PR0.110.3.801-819

Collom, E. (2001). Clarifying the Cross-Class Support for Workplace Democracy. Berkeley Journal of Sociology, 71-103.

Cosby, D. M. (2014). Sustainability Program Leadership for Human Resource Development Professionals: A Competency Model. Journal of Organizational Culture, Communication and Conflict, 18(2), 79-86.

Demerouti, E., Bakker, A. B., \& Leiter, M. (2014). Burnout and Job Performance: the Moderating Role of Selection, Optimization, and Compensation Strategies. Journal of Occupational Health Psychology, 19(1), 96-107. https://doi.org/10.1037/a0035062

Dong, Y., Seo, M. G., \& Bartol, K. M. (2014). No Pain, No Gain: An Affect-Based Model of Developmental Job Experience and the Buffering Effects of Emotional Intelligence. Academy of Management Journal, 57(4), 1056-1077. https://doi.org/10.5465/amj.2011.0687

Dutton, J. E., \& Heaphy, E. D. (2003). The Power of High-Quality Connections. Positive Organizational Scholarship: Foundations of a New Discipline, 3, 263-278.

Fritz, C., Lam, C. F., \& Spreitzer, G. M. (2011). It's the Little Things that Matter: An Examination of Knowledge Workers' Energy Management. The Academy of Management Perspectives, 25(3), 28-39. https://doi.org/10.5465/AMP.2011.63886528

Goldstein, K. (1939). The Organism: A Holistic Approach to Biology Derived from Pathological Data in Man. New York: Zone Books. https://doi.org/10.1037/10021-000 
Grady, R. C. (1990). Workplace Democracy and Possessive Indi vidualism. Journal of Politics, 52(1), 146-166. https://doi.org/10.2307/2131423

Harrison, J. S., \& Freeman, R. E. (2004). Special Topic: Democracy in and Around Organizations: Is Organizational Democracy Worth the Effort? The Academy of Management Executive, 18(3), 49-53. https://doi.org/10.5465/AME.2004.14776168

Hollet-Haudebert, S., Mulki, J. P., \& Fournier, C. (2011). Neglected Burnout Dimensions: Effect of Depersonalization and Personal Nonaccomplishment on Organizational Commitment of Salespeople. Journal of Personal Selling \& Sales Management, 31(4), 411-428. https://doi.org/10.2753/PSS0885-3134310404

Holtzhausen, D. R. (2002). The Effects of Workplace Democracy on Employee Communication Behavior: Implications for Competitive Advantage. An International Business Journal, 12(2), 30-48. https://doi.org/10.1108/eb046440

James, W. (1890). The Principles of Psychology (Volume 2). Henry Holt \& Co. https://doi.org/10.1037/11059-000

Jawahar, I. M. (2012). Mediating Role of Satisfaction with Growth Opportunities on the Relationship Between Employee Development Opportunities and Citizenship Behaviors and Burnout. Journal of Applied Social Psychology, 42(9), 2257-2284. https://doi.org/10.1111/j.1559-1816.2012.00939.x

Kar, S., \& Suar, D. (2014). Role of Burnout in the Relationship between Job Demands and Job Outcomes among Indian Nurses. VIKALPA, 39(4), 23-37. https://doi.org/10.1177/0256090920140403

Khalil, D., Ramzy, O., \& Mostafa, R. (2013). Perception towards Sustainable Development Concept: Egyptian Students' Perspective. Sustainability Accounting, Management and Policy Journal, 4(3), 307-327. https://doi.org/10.1108/SAMPJ-01-2013-0008

Luhman, J. T. (2006). Theoretical Postulations on Organization Democracy. Journal of Management Inquiry, 15(2), 168-185. https://doi.org/10.1177/1056492605275419

Maher, A., \& El-Bedawy, R. (2014). Human Resources Management in Southeastern Asia's Local Government Case Study: Philippine and Thailand. International Journal of Recent Advances in Organizational Behaviour and Decision Sciences, 1(2), 133-147.

Markowitz, L. (1996). Employee Participation at the Workplace: Capitalist Control or Worker Freedom? Critical Sociology, 22(2), 89-103. https://doi.org/10.1177/089692059602200205

Maslow, A. H. (1943). A Theory of Human Motivation. Psychological Review, 50(4), 370. https://doi.org/10.1037/h0054346

Maslow, A. H. (1987). Motivation and Personality (3rd ed.). Addison-Wesley Educational Publishers Inc.

Mason, R. M. (1982). Participatory and Workplace Democracy: A Theoretical Development in Critique of Liberalism. Southern Illinois University Press.

Mortillaro, M., \& Scherer, K. R. (2014). Stressed Out: How Stress Develops and How to Cope with it. GfK Marketing Intelligence Review, 6(1), 16-21. https://doi.org/10.2478/gfkmir-2014-0003

Mourad, M., Ennew, C., \& Kortam, W. (2011). Brand Equity in Higher Education. Marketing Intelligence \& Planning, 29(4), 403-420. https://doi.org/10.1108/02634501111138563

Ozsoy, Z. (2010). ATrue Understanding of Self for Self-Actualization. The Fountain Magazine.

Quinn, R. W., Spreitzer, G. M., \& Lam, C. F. (2012). Building a Sustainable Model of Human Energy in Organizations: Exploring the Critical Role of Resources. The Academy of Management Annals, 6(1), 337-396. https://doi.org/10.1080/19416520.2012.676762

R Core Team. (2014). R: A language and environment for statistical computing. R Foundation for Statistical Computing. Vienna, Austria. Retrieved from http://www.r-project.org/

Ramzy, O., \& Wahieb, R. (2012). Branding the Green Education: Challenges facing Implementation of Education for Sustainable Development in Egypt. Discourse and Communication for Sustainable Education, 3, 83-99. https://doi.org/10.2478/v10230-012-0006-x

Russ-Eft, D. F. (2014). Human Resource Development, Evaluation, and Sustainability: What are the Relationships? Human Resource Development International, 17(5), 545-559. https://doi.org/10.1080/13678868.2014.954190 
Russell, L. M., Cole, B. M., \& Jones, R. J. (2014). High-risk Occupations: How Leadership, Stress, and Ability to Cope Influence Burnout in Law Enforcement. Journal of Leadership, Accountability and Ethics, 11(3), 49-69.

Schippers, M., \& Hogenes, R. (2011). Energy Management of People in Organizations. Journal of Business \& Psychology, 1-33.

Schiuma, G., Mason, S., \& Kennerley, M. (2011). Energy at Work: A Look at Generating a Vital Commodity for Success at Work Today.

Spreitzer, G. M., \& Grant, T. (2011). Helping Students Manage their Energy: Taking their Pulse with the Energy Audit. Journal of Management Education, 1-25.

Stankiewicz, J., Bortnowska, H., \& Łychmus, P. (2014). Conditions Necessary to Maintain Work-Life Balance of Employees in the Light of the Research Results. Management, 18(1), 326-340. https://doi.org/10.2478/manment-2014-0024

Steffens, N. K., Haslam, S. A., Kerschreiter, R., Schuh, S. C., \& Van Dick, R. (2014). Leaders Enhance Group Members' Work Engagement and Reduce their Burnout by Crafting Social Identity. German Journal of Research in Human Resource Management, 28(1-2), 173-194. https://doi.org/10.1177/239700221402800110

Suttapong, K., Srimai, S., \& Pitchayadol, P. (2014). Best Practices for Building High Performance in Human Resource Management. Global Business and Organizational Excellence, 33(2), 39-50. https://doi.org/10.1002/joe.21532

Tavakol, M., \& Dennick, R. (2011). Making Sense of Cronbach's Alpha. International Journal of Medical Education, 2, 53-55. https://doi.org/10.5116/ijme.4dfb.8dfd

Taylor, M. T. S., Schwandt, D. R., \& Casey, A. (2011). Energy and Learning at Work: The Importance of Energy. In Organization Learning, Knowledge and Capabilities Conference (pp. 1-16). University of Warwick.

Verma, R., \& Verm, J. (2012). The Role of Motivation as a Moderator of the Job Demand-Burnout-Performance Relationship among Service Employees in a Social Marketing Campaign. Decision2, 39(3), 68.

Wang, Y., Zheng, L., Hu, T., \& Zheng, Q. (2014). Stress, Burnout, and Job Satisfaction Case of Police Force in China. Public Personnel Management, 43(3), 325-339. https://doi.org/10.1177/0091026014535179

Wiley, J. W. (2014). Using Employee Opinions about Organizational Performance to Enhance Employee Engagement Surveys: Model Building and Validation. People \& Strategy, 36(4), 39-49.

Yüksel, H. (2014). The Concept of Workaholism As The Extreme Point in Work Engagement, Its Indi vidual and Organizational Outcomes. International Journal of Alanya Faculty of Business, 6(2), 119-130.

\section{Copyrights}

Copyright for this article is retained by the author(s), with first publication rights granted to the journal.

This is an open-access article distributed under the terms and conditions of the Creative Commons Attribution license (http://creativecommons.org/licenses/by/4.0/). 